\title{
„Ocena musi być sprawiedliwa” - kilka uwag na temat Akutagawa Ryūnosuke Shō, czyli najpopularniejszej nagrody literackiej w Japonii
}

DOI: http://dx.doi.org/10.12775/LC.2017.062

Streszczenie: Nagroda Akutagawy jest jedną z najbardziej popularnych, prestiżowych i pożądanych nagród w świecie literackim Japonii. Przyznaje się ją dwa razy do roku - w styczniu i lipcu. Utworzona przez Kikuchiego Kana - pisarza, filantropa i prezesa wydawnictwa Bungeishunjūsha, chlubi się ponad osiemdziesięciodwuletnią historią, podczas której zostało nagrodzonych ponad 200 autorów. Przyczynili się oni znacznie do rozwoju japońskiej literatury współczesnej. Co więcej, Nagroda Akutagawy jest od lat w centrum zainteresowania japońskich mass mediów, stanowiąc jedno z najważniejszych dorocznych wydarzeń kulturalnych. Treść artykułu koncentruje się wokół przedstawienia zagadnień takich jak: okoliczności powstania Nagrody Akutagawy, jej historia w zarysie, przyczyna popularności i zainteresowania nią mediów. Wyjaśnia także, jakie wymagania nagroda stawia literaturze i jaką literaturę promuje. Artykuł dodatkowo jest wzbogacony o związane z nagrodą ciekawostki, ale już o nieco swobodniejszym charakterze.

Słowa kluczowe: Nagroda Akutagawy, japońskie nagrody literackie, współczesna literatura japońska, literatura japońska XX wieku, Kikuchi Kan, Bungeishunjū, japońskie media

Adiunkt w Zakładzie Japonistyki Uniwersytetu Mikołaja Kopernika w Toruniu; autorka prac na temat twórczości Tanizakiego Jun'ichirō, teatru japońskiego przełomu XIX i XX wieku oraz powojennej i współczesnej prozy japońskiej. E-mail: marushka@umk.pl. 


\title{
„The judgment must be fair” - some remarks on Akutagawa Prize, the most popular Japanese literary award
}

\begin{abstract}
Akutagawa Prize is one of the most popular, prestigious and desired Japanese literary awards presented semi-annually. Established in 1935 by Kikuchi Kan (along with Naoki Prize awarded to the best work of popular literature) and named in memory of Kikuchi's close friend writer Akutagawa Ryūnosuke, the prize boasts over 82 years of history and had awarded over 200 writers whose works contributed significantly into the development of Japanese modern literature. What is more, it receives considerable and meticulous attention from mass media and is an unmissable part of Japan's annual cultural events. The article focuses on presenting briefly the history of the prize and also attempts to explain what made Akutagawa Prize so popular and prestigious. The author tries to answer: What is the so called "system" of Akutagawa Prize? And if Akutagawa Prize works reflects like a mirror all the changes occurring in Japanese modern society. In addition, the author gives also several examples of opinions of current Akutagawa Prize selection committee members considering the role of literature in the modern world, their expectations towards readers, some memoirs, as well as some trivia that make the story about Akutagawa Prize even more mysterious and involving.
\end{abstract}

Keywords: Akutagawa Prize, Japanese literary awards, Japanese modern literature, Japanese literature in $20^{\text {th }}$ century, Kikuchi Kan, Bungeishunjū, Japanese media

\section{Wstęp}

「純文学でも大衆文学でも、人にたくさん読まれるのが 肝心である。読まれない文芸などは、純文学だろうが何 だろうが、結局飛べない飛行機と同じものである」1

Czy będzie to literatura czysta czy też masowa, niezmiernie ważne jest, by czytana była przez jak najwięcej ludzi. Literatura nieczytana - czy to literatura czysta, czy też literatura masowa, jest niczym samolot, który nie potrafi wzbić się w przestworza $a^{2}$.

- słowa Kikuchiego Kana pochodzące z redagowanej przez niego rubryki Hanashi no kuzubako w miesięczniku „Bungeishunjū” z marca 1935 roku.

M

ikołaj Melanowicz w wydanej w 2003 roku publikacji Formy w literaturze japońskiej po raz pierwszy w historii badań literatury japońskiej w Polsce w bardzo ogólnym

1 T. Ukai, Akutagawa Shō no nazo o toku. Zen senpyō kanzen dokuha, Tōkyō 2015, s. 10.

2 Zamieszczone w prezentowanym tekście wszystkie tłumaczenia cytatów z języka japońskiego pochodzą od autorki artykułu. 
zarysie przedstawia wybrane nagrody literackie przyznawane w Japonii. Już w pierwszym zdaniu otwierającym rozdział poświęcony właśnie tym nagrodom stwierdza, powołując się na Shinchō nihon bungaku jiten (Stownik literatury japońskiej Shinchō): „Od XX wie$\mathrm{ku}$ jedną $\mathrm{z}$ form porządkowania twórczości pisarskiej w Japonii stały się nagrody literackie, których historia sięga końca XIX wieku”’. Nie sposób się z tym nie zgodzić, biorąc pod uwagę bogactwo tamtejszego rynku wydawniczego, mnogość gatunków, tytułów i nazwisk autorów we współcześnie uprawianej literaturze japońskiej. Ogromna ilość nagród w istocie odzwierciedla sytuację wydawniczo-czytelniczą tego kraju. Wśród nich do tych najbardziej znanych, których zdobycie trwale ugruntowuje pozycję pisarza w bundan ${ }^{4}$, należą takie jak chociażby przyznawana od 1941 roku Noma Bungei Shō (Nagroda za Sztukę Literacką) , od 1965 roku Tanizaki Jun'ichirō Shō (Nagroda Tanizakiego) czy Yoshikawa Eiji Bungakushō (Nagroda Literacka Yoshikawy). Wymienienie wszystkich nagród, uwzględniając także te o profilu ogólniejszym, a więc dedykowane twórcom szeroko rozumianej kultury, jak na przykład przyznawana od 1942 roku bardzo prestiżowa Nihon Geijutsuin Shō (Nagroda Japońskiej Akademii Sztuki), podczas ceremonii wręczenia której obecny jest sam cesarz Japonii, wydaje się ze względu na ograniczenia objętościowe prezentowanego tekstu niemożliwe, ale niewątpliwie zasługuje na obszerniejsze opracowanie i przedstawienie. Wśród nagród tych tą współcześnie cieszącą się największą popularnością wśród pisarzy, czytelników, a także większości mass mediów Japonii, jest właśnie Akutagawa Ryūnosuke Shō 芥川龍之介賞, czyli inaczej Nagroda Akutagawy. Jest ona tak osławiona, że nawet samo wyrażenie „nagroda literacka” kojarzone jest właśnie z Nagrodą Akutagawy oraz przyznawaną równocześnie z nią Nagrodą Naokiego. Decydując się na zakup książki, Japończycy często kierują się kryterium zdobytych przez nią lub jej autora laurów. Oficjalna nazwa nagrody to Akutagawa Ryūnosuke Shō (Nagroda Literacka im. Akutagawy Ryūnosuke), ale powszechnie używa się jej w wersji skróconej-Akutagawa Shō (Nagroda Akutagawy). Jest to trofeum literackie w dziedzinie tak zwanej literatury czystej (jap. junbungaku 純文学 w opozycji do literatury popularnej, masowej - taishü bungaku 大衆文学 lub także popyurā bungaku ポピュラー文学). Przyznawana jest dwa razy do roku i kierowana do pisarzy nowych, zupełnie nieznanych lub debiutantów - stawiających pierwsze kroki w świecie literackim Japonii. Jak zauważa Ukai Tetsuo, od lat badający Nagrodę Akutagawy dziennikarz wydawnictwa Yomiuri Shinbunsha: „Nagroda Akutagawy nie jest celem, a startem w pomyślną przyszłość młodego pisarza”. I przykładami pisarzy, którym właśnie sławę i pomyślność w zawodzie pisarza przyniosła, są chociażby takie sławy i legendy japońskiej literatury XX wieku, jak: Abe Kōbo (1924-1993), Yasuoka Shōtarō (1920-2013), Yoshiyuki Junnosuke (1924-1994), noblista japoński Ōe Kenzaburō (ur. 1935), Endō Shūsaku (1923-1996), Kaikō Takeshi (1930-1989) czy Kōno Taeko (1926-2015).

Mimo ponad osiemdziesięciu lat historii i tradycji, dzięki jurorom będącym tylko i wyłącznie pisarzami konsekwentnie stojącymi na straży postulatu „ojca”-fundatora tej nagrody, pisarza Kikuchiego Kana - o promowanie literatury nowej - stanowi ona rodzaj

\footnotetext{
3 M. Melanowicz, Formy w literaturze japońskiej, Kraków 2003, s. 207.

${ }^{4}$ Z jap. „świat literacki, kręgi literackie” - wyrażenie, które narodziło się pod koniec XIX wieku na skutek zetknięcia się japońskich intelektualistów i literatów z tradycjami literackimi Zachodu.

5 Ibidem, s. 210.

6 T. Ukai, op. cit., s. 44.
} 
wyczekiwanego z niecierpliwością dwa razy do roku powiewu świeżego wiatru, aktualnego względem czasów i problemów, którymi czasy te są naznaczone.

Przyznawana dwa razy do roku (zwycięski utwór ogłaszany jest w styczniu i lipcu, natomiast w lutym i sierpniu odbywa się ceremonia wręczenia nagrody) jest jednym z najważniejszych wydarzeń w japońskim kalendarzu imprez kulturalnych, a także - ze względu na wielkie zainteresowanie nią mediów - ucztą dla japońskiego dziennikarstwa. Kiedy i w jakich okolicznościach powstała więc Nagroda Akutagawy? Jak w zarysie przedstawia się jej ponad osiemdziesięcioletnia historia? Co czyni ją tak interesującą i popularną w Japonii? Jakie wymagania stawia literaturze i jaką literaturę promuje? Próba odpowiedzi na te pytania oraz ogólnie rozumiane rozważania wokół Nagrody Akutagawy będą tematem prezentowanego artykułu, wzbogacone dodatkowo o ściśle z nią związane ciekawostki, ale już o nieco swobodniejszym charakterze.

\section{Tradycja przyznawania nagród literackich w Japonii}

Na wstępie należałoby szkicowo przedstawić tradycję przyznawania nagród literackich w Japonii. Otóż koniec XIX wieku w tamtejszym świecie literackim został zdominowany przez napływ utworów z Zachodu. Japończycy stopniowo zapoznawali się z wielością jakże odmiennych prądów i gatunków literackich, to w kontakcie z nimi podejmowali próby pisania w stylu zachodnim, z czasem wypracowując swój własny, rodzimy styl. W rozwoju tradycji nowożytnego rodzimego pisarstwa Japonii końca XIX wieku ważną rolę odegrał teoretyk powieści - Tsubouchi Shōyō (1859-1935), który w swej przełomowej rozprawie Shōsetsu shinzui ( $O$ istocie powieści, 1885) zawarł nowe cele i wymagania stawiane powieści japońskiej. Także ruch genbun itchi, czyli działania dążące do zrównania w literaturze języka pisanego i mówionego, odegrał niemałą rolę w zwiększeniu zainteresowania uprawianiem pisarstwa wśród młodych intelektualistów i nie tylko. Również wydawnictwa prasowe stworzyły korzystne dla autorów warunki publikowania fragmentów ich debiutów literackich w odcinkach na łamach czasopism, tygodników czy dzienników, a z czasem zaczęto organizować plebiscyty-konkursy na najlepszą powieść czy opowiadanie tak zwane kenshōshōsetsu, gdzie wygraną była nagroda pieniężna. Tego typu konkursy były popularne i dominowały aż do chwili pojawienia się Nagrody Akutagawy. Adepci pisarstwa motywowani nadzieją wygrania pieniędzy chwytali za pióro, przyczyniając się w ten sposób niewątpliwie do powstania i rozwoju literatury rodzimej. Okresem szczególnej aktywności prasy w zakresie organizowania konkursów były lata dziewięćdziesiąte XIX wieku. I tak na przykład, jako jeden z pierwszych, bardzo popularny dziennik „Yomiuri shinbun” w 1893 roku ogłosił konkurs z nagrodą pieniężną na powieść oraz dramat. Także tygodnik „Yorozu chōhō” przez kolejne 27 lat nieprzerwanie organizując konkurs na najlepszą nowelę, wypromował wielu pisarzy. Nabory były otwarte - każdy mógł zgłosić swój utwór. Sytuacja uległa zmianie wraz ze schyłkiem ery Meiji. Wówczas to zmienił się system organizowania konkursów - nagradzano utwory nie nowe, a te już napisane, które zostały 
opublikowane na łamach miesięcznika czy dwutygodnika o profilu literaturoznawczym ${ }^{7}$. Celem było wyłonienie utalentowanego pisarza i nagrodzenie wybitnego dzieła spośród już istniejących utworów. Organizatorzy mieli całkowitą swobodę w określaniu warunków konkursu i kryteriów wyłaniania wygranych. Przykładem prekursorskim tej zmiany było na przykład „Bungei senshō” - nagroda ufundowana w 1911 roku przez Komisję ds. Literatury Pięknej Ministerstwa Edukacji Japonii (Monbushō) i wręczana z rąk samego ministra. Warto dodać, że jednym z jej pomysłodawców i inicjatorów był pisarz Mori Ōgai (1862-1922), który podczas swego pobytu na studiach w Niemczech miał okazję usłyszeć o najważniejszych plebiscytach literackich z gratyfikacją pieniężną odbywających się w Europie, jak chociażby Nagroda Goncourtów czy literacki Nobel. Zapragnął trend ten zaszczepić na gruncie rodzimym. Oczywiście byli też przeciwnicy takiej formy promowania twórczości, argumentując swoje stanowisko obawą o jej skomercjalizowanie. Mianowicie obawiano się, że motywacja zdobycia łatwego pieniądza znacznie obniży poziom zgłaszanych na konkurs utworów ${ }^{8}$.

\section{Kikuchi Kan - dramatopisarz, filantrop, prezes}

W trend organizowania nagrody literackiej w ramach czasopisma wpasował się także Kikuchi Kan 菊池寛 (1888-1948) ${ }^{9}$ - wówczas prezes wydawnictwa Bungeishunjūsha i redaktor naczelny wydawanego przez nie miesięcznika poświęconego społeczeństwu i kulturze - „Bungeishunjū”. Stworzony przez niego profil nagrody i absolutnie nowatorskie zasady jej przyznawania wyznaczyły nową jakość na rynku wydawniczym Japonii, z czasem czyniąc Nagrodę Akutagawy bezkonkurencyjną w zakresie popularności i spektakularności. Najpierw jednak należałoby nieco przybliżyć sylwetkę Kikuchiego, jego działalność i środowisko pracy.

Kikuchi był ważną postacią japońskiego bundan okresu Taishō - talent organizacyjny przejawil, zawiązując w 1920 roku Stowarzyszenie Dramatopisarzy, a rok później Stowarzyszenie Prozaików. Organizacje kierowane przez Kikuchiego oprócz promowania literatury, zajmowały się poprawieniem sytuacji materialnej pisarzy, obroną ich interesów, przestrzeganiem praw autorskich i godziwych honorariów. W 1926 roku stowarzyszenia te połączyły się i od tej pory były nazywane Stowarzyszeniem Literatów. Uważany za najwybitniejszego dramaturga ruchu Jiyū Gekijō (Wolny Teatr) - prowadzonego przez Osanai Kaoru - za własne oszczędności, które posłużyły za kapitał początkowy, założył w styczniu 1923 roku firmę - wydawnictwo Bungeishunjūsha ${ }^{10}$.

Wspomniany talent organizacyjny i filantropijne podejście względem ludzi trudniących się pisarstwem, a przede wszystkim chęć poprawienia sytuacji materialnej debiutujących pisarzy, którzy nie zawsze zyskowne pisanie obrali jako sposób na życie, były główny-

\footnotetext{
7 N. Kawaguchi, Akutagawa Shō monogatari, Tōkyō 2013, s. 16.

8 Ibidem, s. 17.

9 J. Miyauchi, Kikuchi Kan, [hasło w:] Nihon gendai bungaku daijiten. Jinmei. Jikō hen, red. Y. Miyoshi et al., Tōkyō 1994, s. 109.

10 T. Ukai, op. cit., s. 20.
} 
mi determinantami Kikuchiego do stworzenia Nagrody Akutagawy i Nagrody Naokiego. Chęć zysku - w odróżnieniu od innych czasopism - pozostawała kwestią drugorzędną. Jednak najważniejszym celem przyświecającym działaniom Kikuchiego była chęć uczczenia pamięci jego dwóch zmarlych przyjaciól ${ }^{11}$ : pisarzy Naokiego Sanjūgo (1891-1934) oraz Akutagawy Ryūnosuke (1892-1927), a dzięki temu ożywienie działalności czasopisma i nadanie mu świeższego, nowocześniejszego charakteru. Naoki - autor napisanej w 1931 roku znanej powieści masowej Nangoku taiheiki 南国太平記 (Kronika wielkiego pokoju krain południowych) i Akutagawa - geniusz literatury czystej i mistrz opowiadania, często pisywali do „Bungeishunjū” i już jako pisarze uznani, rozpoznawani przyczyniali się do zwiększenia nakładu, a tym samym zysku z czasopisma. Możliwe też, że Kikuchi chciał się w ten sposób odwdzięczyć i uhonorować przyjaciół po ich śmierci.

Tak więc w styczniowym numerze czasopisma w 1935 roku ogłosił powstanie dwóch nagród literackich i nazwanie ich imionami swych zmarłych przyjaciół. Celem konkursów natomiast miało być wsparcie rozwoju literatury japońskiej. Zapowiedział także, że wydawnictwo Bungeishunjūsha będzie fundatorem głównej nagrody - pieniędzy w obu konkursach. Zaznaczył też, że do współzawodnictwa można zgłaszać utwory, które będą opublikowane w różnych czasopismach literackich w ciągu pierwszego półrocza 1935 roku. Jasno też określił cel konkursu i jego regulamin ${ }^{12}$ :

1. Nagroda Akutagawy będzie przyznana wybitnej osobie, której utwór został już opublikowany na łamach czasopisma o tematyce literackiej i której nazwisko jest jeszcze nieznane lub osoba ta jest nowym autorem.

2. Nagrody rzeczowe to zegarek kieszonkowy-dewizka i oprócz tego nagroda pieniężna w wysokości 500 jenów $^{13}$.

3. Wyłanianiem zwycięzcy zajmie się kapituła nagrody, a członkami jej będą następujące osoby, które łączyły przyjacielskie stosunki ze zmarłym Akutagawą oraz firmą - wydawnictwem Bungeishunjūsha: prezes Kikuchi Kan, Kume Masao 久米正雄, Yamamoto Yūzō 山本有三, Satō Haruo 佐藤春夫, Tanizaki Jun’ichirō, Murō Saisei 室生姩星, Kojima Masajirō 小島政二郎, Sasaki Mosaku 佐佐木茂索, Takii Kōsaku 滝井孝作 (najdłużej w historii, juror od pierwszej do osiemdziesiątej szóstej edycji), Yokomitsu Ri’ichi 横光利一, Kawabata Yasunari 川端康成.

4. Członkowie jury będą się spotykać i obradować co 6 miesięcy. W przypadku braku odpowiedniego kandydata nagroda nie zostanie przyznana.

5. Zwycięski utwór zostanie $\mathrm{w}$ całości opublikowany na łamach czasopisma „Bungeishunjū”.

Kikuchi dodał też zamieszczone w tytule tego artykułu zdanie: Shinsa wa zettai kōhei 審査は絶対公平 akcentujące, że proces ewaluacji nominowanych utworów ma być bez-

11 Kikuchi był bliskim przyjacielem Akutagawy. Razem reaktywowali czasopismo literackie "Shinshichō IV” (1916-1917) - jego czwartą edycję. To w numerze inicjującym działalność pisma Akutagawa zamieścił swe opowiadanie Hana, które zostało wyjątkowo entuzjastycznie zrecenzowane w świecie literackim przez samego mistrza Natsume Sōsekiego. Zaś przyjaźń Kikuchiego z Naokim rozpoczęła się od zaproszenia Kikuchiego przez Naokiego do współpracy przy zawiązywaniu Rengo Geijutsuka Kyōkai (Stowarzyszenie Artystów Filmowych) w 1925 roku.

12 T. Ukai, op. cit., s. 32.

13 Współcześnie jest to także zegarek kieszonkowy i kwota w wysokości 1 mln jenów japońskich (ok. 30000 zł). 
względnie sprawiedliwy. Zaznaczył także, że bycie jurorem zobowiązuje również do pozakonkursowego wspierania zwycięzcy w rozwoju jego kariery literackiej ${ }^{14}$.

W chwili ustanowienia Nagrody Akutagawy w świecie literackim Japonii lat trzydziestych XX wieku istniały już dwie bardzo poważane i cieszące się popularnością nagrody przyznawane pisarzom debiutującym przez czasopisma „Kaizō” oraz „Chūōkōron”. Raz do roku organizowały one nabór na utwory konkursowe i swą próbę pisarską mógł zgłosić każdy. Nie miały one jednak jury jak Nagroda Akutagawy, gdyż o zwycięstwie rozstrzygali pracownicy redakcji czasopisma podczas wewnętrznego głosowania. Jakże więc przełomowa i pionierska musiała być Nagroda Akutagawy, która nie dość, że do jury zapraszała najwybitniejszych japońskich mistrzów pióra, to jeszcze dodatkowego splendoru dodawał jej fakt, że zwycięski utwór w całości zamieszczano na łamach czasopisma „Bungeishunjū”.

Powszechny podziw i uznanie wśród czytelników czy w kręgach literackich budził sposób, w jaki przeprowadzano procedury konkursowe. A mianowicie, jak celnie wskazuje Ukai, Nagroda Akutagawy to zamknięty system, w skład którego wchodzą: nominowane utwory, obrady jury, recenzje jurorów. Żadna nagroda tego nie posiadała. Poza tym Nagroda Akutagawy w odróżnieniu od kenshōshōsetsu nie była komercyjna. Oznaczała ona nową jakość w świecie literackim i na rynku wydawniczym. Te wszystkie walory czyniły ją wyróżnieniem prestiżowym oraz w pewien sposób ekskluzywnym. To być może także tłumaczy, dlaczego Nagrody „Chūōōron” i „Kaizō” przetrwały tylko do 1939 roku. Jak wyglądał więc nabór utworów w początkowej fazie istnienia nagrody?

Otóż to jurorzy zajmowali się organizowaniem naboru kandydatów do nagrody. Polegało to na wysłaniu listu w formie ankiety do pisarzy, krytyków literackich czy dziennikarzy periodyków poświęconych literaturze z prośbą o wskazanie kandydata i uzasadnienie decyzji. Selekcjonowali nadesłane propozycje, czytając wszystkie utwory, a następnie w wyniku dyskusji zakończonej głosowaniem wyłaniali zwycięzcę. Podczas ogłaszania laureata nie zapominano o podziękowaniach dla rekomendujących zwycięski utwór respondentów. I tak na przykład podczas ogłoszenia wyników pierwszej edycji podziękowania otrzymali: pisarka Hirabayashi Taiko (1905-1972), Ibuse Masuji (1898-1993), Itō Sei (1905-1969), Hayashi Fumiko (1903-1951) - łącznie aż 38 osób. Z kolei druga edycja została uświetniona rekomendacjami takich tuzów jak na przykład pisarz Shiga Naoya (1883-1971) czy najwybitniejszy w dziejach japońskiej literatury jej krytyk Kobayashi Hideo (1902-1983). Nietrudno zauważyć, że obecność takich nazwisk już w fazie wstępnej konkursu - na etapie rekomendacji utworów - świadczyła o tym, że Kikuchi Kan od samego początku wysoko postawil poprzeczkę, określając standardy przyznawania Nagrody Akutagawy.

Nagai Tatsuo (1904-1990) - pisarz, jeden z redaktorów „Bungeishunjū”, pracujący przy nagrodzie od początku jej powstania, zajmujący się nominowanymi utworami, a także wszelkimi sprawami organizacyjnymi, w wydanych przez siebie wspomnieniach na temat obu nagród Kaisō Akutagawa. Naoki Shō w dość filuterny sposób definiuje nagrodę: „Krótko mówiąc: Nagroda Akutagawy to młoda panienka tryskająca świeżością i pełnią życia. Ponad wszystko jurorów przekonuje świeżość", a dalej porównując Nagrodę Naokiego do gejszy ${ }^{15}$. Takie porównanie Nagrody Akutagawy wydaje się w miarę trafne, gdyż w istocie to jurorzy

\footnotetext{
14 T. Ukai, op. cit, s. 32.

15 T. Nagai, Kaisō Akutagawa. Naoki Shō, Tōkyō 1982, s. 13.
} 
wyłaniają - często nawet w atmosferze burzliwej dyskusji - nowego autora, którego twórczość otworzy nowy rozdział w historii literatury japońskiej.

Wracając jednak do przedstawienia kilku faktów z historii nagrody, należy w tym miejscu uzupełnić, że początkowo jej organizatorem był Komitet Nagrody Akutagawy, jednak jeszcze w tym samym roku powołano działające do dziś Towarzystwo Promocji Literatury Japońskiej (Nihon bungaku shinkōkai 日本文学振興会). Jego prezesem został Kikuchi, a zastępcą Sasaki Mosaku' ${ }^{16}$ (1894-1966). Obrady jurorów pierwszej edycji i ogłoszenie wyników nastąpiło w sierpniu 1935 roku. Wielkim zwycięzcą został Ishikawa Tatsuzō (1905-1985; późniejszy członek kapituły Nagrody Akutagawy) i jego utwór Sōbō 蒼呡 (Zwykli ludzie). Zaś wielkim przegranym pierwszej edycji był pisarz Dazai Osamu $\mathrm{z}$ utworem Gyakkō 逆行 (Pod prą). W tym miejscu trzeba nadmienić, że wątek przegranej Dazaia jest nieodłącznym i obecnym w niemal każdym opracowaniu poświęconym historii Nagrody Akutagawy ${ }^{17}$. Niepogodzenie się pisarza z werdyktem jurorów, histeria i agresywna korespondencja, jaką prowadził z krytykującym go merytorycznie Kawabatą Yasunarim (wówczas trzydziestosześcioletnim - najmłodszym członkiem jury) są jednym z ważniejszych wydarzeń w dziejach historii literatury japońskiej. Jest to wątek wyjątkowo intrygujący i wart przybliżenia, jednakże ze względu na ograniczenia objętościowe tego tekstu, nie może w tym miejscu zostać rozwinięty.

Warto dodać, że już w 1938 roku ukazało się pierwsze sześciotomowe wydanie dzieł zebranych Nagrody Akutagawy. Przyczyniło się to do wzrostu zainteresowania samym konkursem, ale także zmobilizowało rzesze pisarzy dopiero marzących o debiucie literackim do zgłaszania swych utworów ${ }^{18}$. Także na 1938 rok przypada pierwsza laureatka - kobieta. Dwudziestodziewięcioletnia Nakazato Tsuneko (1909-1987), bo o niej mowa, przerwała okres dominacji męskich zwycięzców nagrody. Obecność kobiet w Nagrodzie Akutagawy zawsze dodawała jej nieco smaku. Kolejnym podwójnym kobiecym sukcesem cieszyły się już potem tylko Kanehara Tomomi i Wataya Risa. Do tej pory (rok 2017) odbyło się 157 edycji Nagrody Akutagawy. Od chwili powstania przyznawana była regularnie - nawet podczas II wojny światowej, gdy uwaga społeczeństwa skierowana była na wydarzenia na froncie i działania wojenne armii japońskiej, a wszechobecna ingerencja aparatu państwowego w życie obywateli, cenzura prasy i literatury niezbyt przecież mogły sprzyjać kontynuowaniu wszelkich wydarzeń kulturalnych. Smutnym faktem było też to, że wielu młodych utalentowanych ludzi zostało wcielonych do wojska, tak więc rzadko kto mógł zgłaszać swe utwory do konkursu.

Echo wojny odbiło się także na tematyce zgłaszanych utworów (co ciekawe, w tym także przez pisarzy wysłanych na front wojenny), wśród których dominowała śmierć na polu walki, odpowiedzialność za pozostawienie wdów i dzieci, rozterki walczących w koloniach i rozważania na temat wojny w ogóle ${ }^{19}$. Warto dodać, że zgłaszanych utworów było coraz mniej, a ich poziom zaczynał być zatrważająco niski. Dlatego też po zapoznaniu się z no-

\footnotetext{
16 Były wychowanek Akutagawy. Próbował swych sił jako pisarz, jednocześnie pracując między innymi w wydawnictwie Shinchōsha. W 1929 roku zarzucił pisanie, by całkowicie poświęcić się pracy w „Bungeishunjū”, którego został redaktorem naczelnym. Był członkiem jury w Nagrodzie Akutagawy od pierwszej do szesnastej edycji (lata 1935-1942). Zob. E. Ebii, Sasaki Mosaku, [hasło w:] Nihon gendai bungaku daijiten. Jinmei. Jikō hen, s. 157.

17 K. Saeki, Akutagawa Shō o toranakatta meisakutachi, Tōkyō 2009, s. 11-31.

18 N. Kawaguchi, op. cit., s. 38.

19 T. Ukai, op. cit., s. 54.
} 
minacjami do dwudziestej edycji nagrody, jeden z jej jurorów Takii Kōsaku wystąpił z propozycją, by może zrobić kilka lat przerwy w przyznawaniu wyróżnień na czas odbudowania jej obecnie niskiego poziomu ${ }^{20}$. Tak się jednak nie stało, ale rzeczywiście nad Nagrodą Akutagawy, a właściwie nad całym wydawnictwem Bungeishunjūsha i podlegającym mu Towarzystwie Promocji Literatury Japońskiej (będącym organizatorem przedsięwzięcia) zawisły czarne chmury. Problem dotyczył ograniczeń dystrybucji papieru na rynku oraz pogarszającej się sytuacji finansowej firmy ${ }^{21}$. Także w listopadzie 1945 roku, a więc niespetna 3 miesiące od ogłoszenia przez Japonię bezwarunkowej kapitulacji, mimo rozpoczętego naboru utworów, anulowano dwudziestą pierwszą edycję na czas nieokreślony. Była to decyzja jurorów, gdyż z powodu zawieszenia działalności wydawniczej czasopism, które rekomendowały nominowane książki, pojawiło się zbyt mało zgłoszeń. Również sam Kikuchi Kan w marcu 1946 roku podją decyzję o zamknięciu firmy Bungeishunjūsha, która dzięki determinacji Sasakiego Mosaku i załogi bliskich współpracowników wydawnictwa została szczęśliwie reaktywowana. Nową firmę nazwano Bungeishunjūshinsha, a jej prezesem został właśnie Sasaki Mosaku.

W marcu 1948 roku zmarł Kikuchi, a jego ostatnią wolą było wskrzeszenie Nagrody Akutagawy. Stało się to dopiero na początku 1949 roku. Nagroda powróciła w dwudziestej pierwszej edycji w iście spektakularny sposób, a to dlatego, że nie tylko przyznano podwójne zwycięstwo - tryumfowali Yuki Shigeko i Kotani Tsuyoshi, ale także z powodu prestiżu jury - znalazły się w nim najwybitniejsze sławy japońskiej literatury: wspomniany wcześniej laureat pierwszej edycji nagrody Ishikawa Tatsuzō, Uno Kōji (1891-1961), Kawabata Yasunari, Kishida Kunio (1890-1954), Sakaguchi Angō (1906-1955), Takii Kōsaku, Niwa Fumio (1904-2005), Funahashi Seiichi (1904-1976) ${ }^{22}$. Od tamtej pory jest przyznawana nieprzerwanie i kolejna jej edycja będzie już sto pięćdziesiątą ósmą.

\section{Akutagawa Shō współcześnie}

Obecnie wyłanianie laureata Nagrody Akutagawy odbywa się w następujący sposób: organizator - Towarzystwo Promocji Literatury Japońskiej zwołuje redaktorów na stałe pracujących w wydawnictwie Bungeishunjūsha, by dokonali wstępnej selekcji zgłoszonych do konkursu utworów. Przedmiotem weryfikacji konkursowej mogą być utwory pisane prozą: opowiadanie, nowela lub krótka powieść. To oni czytają po kolei wszystkie tytuły, następnie $\mathrm{w}$ drodze ich omawiania i głosowania wyłaniają od 5 do 7, które zostają zakwalifikowane do finału, przedstawione jurorom do przeczytania i recenzji. Punktem kulminacyjnym obrad komitetu jurorów jest spotkanie za zamkniętymi drzwiami - tak zwane senkōkai 選考会, podczas którego, drogą głosowania, zostaje wyłoniony ostateczny zwycięzca ${ }^{23}$. Obecnie w kapitule nagrody zasiadają: pisarki Ogawa Yōko (ur. 1962), Kawakami Hiromi (ur. 1958), Takagi Nobuko (ur. 1946), Yamada Eimi (ur. 1959) oraz pisarze Okuizumi

\footnotetext{
Ibidem, s. 79.

N. Kawaguchi, op. cit., s. 59.

Ibidem.

T. Ukai, op. cit., s. 229.
} 
Hikaru (1956), Shimada Masahiko (ur. 1961), Horie Toshiyuki (ur. 1964), Miyamoto Teru (ur.1947), Murakami Ryū (ur. 1952) i Yoshida Shūichi (ur. 1968).

\section{Tajemniczy wieczór w Shinkiraku}

Co roku w styczniu i lipcu jurorzy spotykają się w powstałej pod koniec XIX wieku restauracji Shinkiraku 新喜楽, znajdującej się na terenie słynnego targu rybnego Tsukiji w Tokio. Zajmują pomieszczenie na pierwszym piętrze (na drugim piętrze obradują w tym samym czasie jurorzy Nagrody Naokiego). Siedzą przy stole w kształcie odpowiadającym japońskiej sylabie „ko” コ - zapisanej znakiem katakany. Najstarszy ze zgromadzonych siedzi na środku. Całość spotkania prowadzi redaktor naczelny miesięcznika „Bungeishunjū” pełni on funkcję sekretarza kapituły. Głosujący jurorzy w kolejności wypowiadają się na temat każdego nominowanego utworu (jest ich od 5 do 7), a na koniec każdemu przyznają punkty, podając jeden z trzech możliwych symboli: $\bigcirc \Delta x$ (odpowiadający kolejno: 1 pkt, 0.5 pkt, 0 pkt). Następnie punkty są sumowane i odczytuje się wynik głosowania. Gdy jest on niejednoznaczny, jurorzy kontynuują obrady, rozstrzygając go w toku dysku$\mathrm{sji}^{24}$. Szczegóły głosowania nie są publikowane w prasie, są objęte tajemnicą. Wyniki głosowania i opinie jurorów, a uściślając - napisane przez nich krytyczne recenzje (tak zwane senpyō) nominowanych utworów, są publikowane odpowiednio w marcowym i wrześniowym numerze „Bungeishunjū” wraz ze zwycięskim utworem (czasopismo ukazuje się zawsze miesiąc wcześniej).

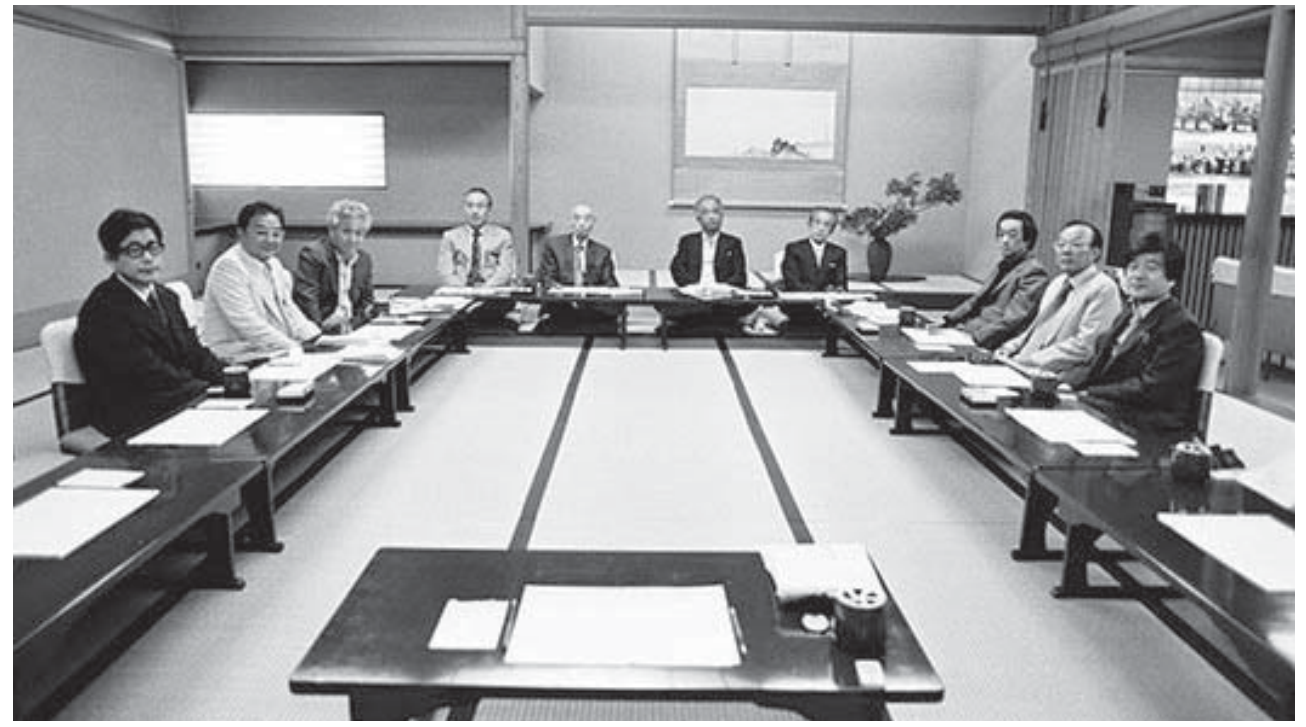

Obrady komitetu jurorów (senkōkai) w 53 roku Shōwa (1978) mające wyłonić laureata 79. edycji

Nagrody Akutagawy. Od lewej strony siedzą: Ōe Kenzaburō, Kaikō Takeshi, Yasuoka Shōtarō,

Niwa Fumio, Takii Kōsaku, Nakamura Mitsuo, Inoue Yasushi, Yoshiyuki Junnosuke, Endō Shūsaku i Maruya Saiichi (fotografia udostępniona dzięki uprzejmości @ BUNGEI SHUNJU).

24 Ibidem, s. 8. 
Przez ponad 82 lata historii tej nagrody jurorzy konsekwentnie przestrzegali i nadal przestrzegają kardynalnej zasady wprowadzonej przez pomysłodawcę - „ojca” nagrody Kikuchiego Kana, mianowicie Shinsa wa zettai kōhei, czyli „ocena musi być sprawiedliwa”. Wśród nich znajdują się pisarze bardziej lub mniej popularni, wpływowi czy ze względu na wybitne osiągnięcia dominujący w kręgach literackich, jednakże w sali obrad wszyscy zebrani są sobie równi, dysponują jednym głosem, mają jasno postawione cele do wykonania, z których najważniejszy to oczywiście wybranie zwycięskiego utworu i napisanie recenzji ogólnej wszystkich zgłoszonych do finału tytułów. W tym miejscu warto odwołać się do wspomnień pisarki Kōno Taeko, zwyciężczyni czterdziestej dziewiątej edycji nagrody, a także pierwszej w całej jej historii kobiety-jurorki ${ }^{25}$. Wspomina ona, że na wieść o wybraniu jej do kapituly z gratulacjami jako pierwszy zadzwonił do niej jej mistrz, pisarz Niwa Fumio (wówczas już były członek tej kapituły). Udzielił jej wówczas wskazówki, którą ta kierowała się już do końca pełnienia swych obowiązków w jury: „Nigdy nie ulegaj opinii innych jurorów, tylko wypowiedz na głos swoją własną! Nie będą cię tam traktować poważnie, gdy będziesz budowała swoją recenzję na opinii kogoś innego!”26. Ogawa Yōko czterokrotnie nominowana do nagrody, a w końcu w 1990 roku jej laureatka za powieść Ninshin karendā 妊娠カレンダー (Kalendarz ciąży), obecnie członkini kapituły (od sto trzydziestej siódmej edycji), także tam wspomina, jak odreagowuje stres i zmęczenie po wieczorze jurorów w Shinkiraku:

Po zakończeniu obrad wracam zazwyczaj prosto do hotelu ${ }^{27}$. Następnie wychodzę na świeże powietrze i okrążam kilka razy pobliski park. Mogę wówczas opanować podenerwowanie. Raz kiedyś w wieczór, gdy przepadł z kretesem utwór, na który głosowałam, spacerowałam po parku tak długo, aż miałam odciski na stopach. Kiedy już uda mi się nieco wyciszyć, wracam do hotelu pisać recenzję $e^{28}$.

Recenzja, o której mowa, to - jak już nadmieniono wcześniej - obok nominowanych utworów i obrad jury, jeden z trzech niezbędnych elementów składowych systemu, jakim jest Nagroda Akutagawy. Zadaniem jurorów jest wyłonienie zwycięzcy konkursu w drodze głosowania oraz dyskusji, ale także napisanie recenzji, w której każdy z nich powinien odnieść się względem nie tylko utworu zwycięskiego, ale wszystkich pozostałych nominowanych utworów. Recenzja ta nie jest zwyczajną recenzją dzieła literackiego. Juror-pisarz najpewniej konfrontuje w niej swoje pisarskie doświadczenie, spojrzenie na literaturę i artystyczną wrażliwość z recenzowanym materiałem literackim. Musi obiektywnie i, co najważniejsze, sprawiedliwie odnieść się do utworu z dwóch perspektyw: pisarza i zarazem czytelnika. Recenzja stanowi także sprawozdanie z pola walki - przebiegu obrad jury, gdzie nierzadko dochodzi również do ostrej wymiany zdań niezgadzających się ze sobą stron.

\footnotetext{
25 Kōno Taeko zasiadała w kapitule Nagrody Akutagawy w latach 1987-2006. Razem z nią w 1987 roku do kapituły nagrody dołączyła też Oba Minako - laureatka pięćdziesiątej dziewiątej edycji w 1968 roku. To przełomowe wydarzenie sprawiło, że nazwiska pisarek nie schodziły wówczas długo z pierwszych stron najważniejszych japońskich gazet.

26 K. Taeko, Shiryō o yuka ni nagetsuketa koto mo aru „,Bungeishunjū” 2014, nr 3, s. 270-273.

27 Ogawa mieszka w Ashiya niedaleko Kobe.

28 Y. Ogawa et al., Akutagawa Shō 150 kai kinen tokushū. Sakka no honne daizadankai, „Bungeishunjū” 2014, nr 3, s. 291.
} 
Obrady trwają łącznie około dwóch godzin, podczas których jurorzy także jedzą i piją (w tym również alkohol). Werdykt jury zapisany na kartce papieru zostaje przekazany sekretarzowi Towarzystwa Promocji Literatury Japońskiej, a ten schodzi na dół do poczekalni restauracji, gdzie czekają w zniecierpliwieniu pracownicy wydawnictwa oraz dziennikarze bowiem kulisy żadnych zmagań literackich w Japonii nie są tak szeroko dyskutowane w mediach jak właśnie Nagrody Akutagawy. Sekretarz zawiesza na tablicy kartkę z nazwiskiem autora i tytułem zwycięskiego utworu. Krótko po tym rozpoczyna się szybka konferencja prasowa z udziałem jury, a po tym wszyscy zainteresowani przenoszą się do Teikoku Hotel (Hotel Cesarski w Tokio) na konferencję prasową zwycięzcy i bankiet ${ }^{29}$.

\section{„Nagrody nie przyznano”}

Tak przedstawiają się w skrócie kulisy prac organizatorów i jurorów w sytuacji, gdy nagroda jest przyznawana. Jednak zdarza się i tak, że czasem się jej nie przyznaje i wówczas w mediach czy kręgach literackich wrze. Taka sytuacja w przypadku Nagrody Akutagawy nazywa się gaitō saku nashi 該当作なし i właściwie wpisana jest już w tradycję tego konkursu. Na 156 edycji nagrody, które odbyły się do tej pory (stan na I półrocze 2017 roku), aż 31 razy (począwszy od edycji) nie wybrano zwycięskiego utworu. Rekord częstotliwości padł w latach osiemdziesiątych, a dokładnie w okresie 1980-1989, gdy aż dziewięć razy jury nie nagrodziło nikogo. Ostatni raz do takiej sytuacji doszło w 2010 roku podczas sto czterdziestej piątej edycji nagrody. Nieprzyznanie lauru jest sytuacją przykrą nie tyle dla samych nominowanych, co także dla jurorów, którzy z ciężkim sercem musieli wypracować jakże niechciany kompromis i podjąć właśnie taką decyzję. Kiedy zapada decyzja o nieprzyznaniu nagrody? Dzieje się tak wówczas, gdy jurorzy wśród nominowanych utworów nie znajdują ani jednego, który zasługiwałby na wyróżnienie. Ale też w sytuacji, gdy ich głosy rozkładają się mniej więcej po równo i trudno wypracować jakikolwiek kompromis, nawet gdy toczą burzliwe dyskusje i spory, by jednak komuś tę nagrodę wręczyć. O tym, że sami jurorzy bardzo nie lubią sytuacji, kiedy nie zostaje wybrany żaden zwycięzca, najdobitniej mogą świadczyć słowa wspomnianej już pisarki Kōno Taeko. W wymienionym już jubileuszowym wydaniu specjalnym miesięcznika „Bungeishunjū” w marcu 2014 roku przywołuje ona sytuację, gdy podczas senkōkai była nieparzysta liczba jurorów i to od jej głosu zależało, czy zwycięzca będzie wyłoniony, czy też nie. Kōno nie miała problemu z podjęciem decyzji, gdyż debatowano nad utworem, który był faworytem pisarki ${ }^{30}$. Cytowany już kilkakrotnie Ukai z własnej dziennikarskiej perspektywy dodaje, że dla dziennikarzy przygotowanych na medialne show informacja o nieprzyznaniu nagrody jest równie przykra, co dla nominowanych czy jurorów. Konstatuje też, że na sytuacji tej jednak najbardziej cierpi - pod względem ekonomicznym - wydawnictwo Bungeishunjū, gdyż zwyczajnie nie osiąga obliczanego na rekordowy zysku ze sprzedaży numeru, w którym mógłby znaleźć się zwycięski utwór. W tym miejscu warto przywołać osobliwy przypadek pisarza Shimady Masahiko. Otóż ubiegał się on o Nagrodę Akutagawy łącznie w 6 jej edycjach, z czego w 5 z nich juro-

\footnotetext{
29 T. Ukai, op. cit., s. 12.

30 T. Kōno, Shiryō o yuka ni nagetsuketa koto mo aru ,"Bungeishunjū” 2014, nr 3, s. 270-273.
} 
rzy postanowili nikogo nie nagradzać. Co ciekawe, tak doświadczony Shimada określił działanie jurorów „niczym innym niż znęcaniem”, a dziś sam jest jurorem Nagrody Akutagawy od sto czterdziestej czwartej jej edycji (od 2010 roku). Sytuacji gaitō saku nashi doświadczył też nominowany w 1983 roku w osiemdziesiątej trzeciej edycji najbardziej współcześnie znany na świecie japoński pisarz Murakami Haruki (powieść Sen kyū hyaku nanajū sannen no pinbōru一九七三年のピンボール, Flipper roku 1973). Przykład jego kariery będącej pasmem sukcesów i wciąż gigantycznej wręcz popularności nie tylko w Japonii, ale przede wszystkim poza jej granicami świadczy, że niektóre „świeże” talenty przeoczone przez kapitułę Nagrody Akutagawy (Murakami był aż dwukrotnie nominowany), zauważone zostają głównie tam, gdzie kwestia prestiżu tej nagrody jest sprawą drugorzędną. Także znana i uwielbiana na całym świecie autorka przetłumaczonej na język polski Kitchin キッチン (Kuchnia) - Yoshimoto Banana, mimo dwukrotnej nominacji w 1988 roku, ani razu lauru tego nie otrzymała. Warto dodać, że niepowodzenia Murakamiego, a także trzykrotnie nominowanej do tej nagrody wybitnej pisarki Tsushimy Yūko czy wspomnianego Shimady Masahiko, zostały im zrekompensowane przyznaniem Nagrody Nomy (Noma Bungei Shinjin Shō), której kapitułę stanowią krytycy literaccy. Fakt ten może stanowić ważny punkt wyjścia dla dyskusji na temat wagi obu nagród - Akutagawy i Nomy ze względu na kompetencje literaturoznawcze przyznających je członków jury.

Czasem jednak zdarza się i tak, że jurorzy - jakby chcąc wynagrodzić pisarzom, czytelnikom czy dziennikarzom rozczarowanie towarzyszące edycji „bez nagrody” - wyłaniają dla odmiany parę zwycięzców w kolejnych edycjach. W roku 2004 taką najbardziej znaną parą ${ }^{31} \mathrm{w}$ dziejach Nagrody Akutagawy były dwie najmłodsze w jej historii pisarki dziewiętnastoletnia wówczas Kanehara Hitomi (za powieść Hebi ni piasu 蛇にピアス, Języki i kolczyki ${ }^{32}$ ) i dwudziestoletnia Wataya Risa (za Keritai senaka 蹴りたい背中, Kopnę cię). Podwójne zwycięstwo dwóch młodziutkich dziewcząt wywołało „gorączkę” medialną w Japonii, a same pisarki wspominają, jak musiały poruszać się w towarzystwie ochroniarzy, gdyż gdziekolwiek się pojawiały, rozeuforyzowany tłum żądny autografów mógł je stratować ${ }^{33}$. Ich sukces miał przełożenie na rekordowy wówczas nakład marcowego „Bungeishunjū”, który wyniósł 1805000 sztuk. Ostatni raz sytuacja podwójnego zwycięstwa zaszła w styczniu 2016 roku, gdy wyróżniono ex aequo Takiguchiego Yūshō (ur. 1982) za utwór Shinde inai mono 死んでいないもの (Ci, co jeszcze nie zmarli) i Motoyę Yukiko (ur. 1979) za utwór Irui kon'in tan 異類婚姻譚 (Opowieści o matżeństwach osobliwych). Łącznie takich przypadków podwójnego zwycięstwa w całej historii nagrody było do tej pory aż trzydzieści dziewięć.

\footnotetext{
31 Pierwszą w historii zwycięską parą żeńską były Yamamoto Michiko i Gō Shizuko - dwie gospodynie domowe (sengyō shufu), które otrzymały nagrodę podczas sześćdziesiątej ósmej edycji w 1973 roku. Wydarzenie to długo było z zachwytem komentowane w mediach.

32 T. Kanehara, Języki i kolczyki, tłum. z j. angielskiego W. Nowakowski, Warszawa 2007.

33 Y. Ogawa et al., op. cit., s. 282-293.
} 


\section{Ciekawostki związane z Nagrodą Akutagawy}

Skoro mowa o liczbach i wydarzeniach przełomowych, niepowszednich, to na zakończenie warto przytoczyć kilka ciekawych przypadków z historii nagrody. Jak wspomniano, w składzie obecnego jury zasiada Shimada Takehiko, który mimo wielokrotnych nominacji nigdy nie zdobył głównego lauru. Jest tam też i Yamada Eimi - pisarka ciesząca się międzynarodową sławą, której mimo trzykrotnej nominacji również nie było dane cieszyć się zwycięstwem. Z pokolenia starszych jurorów także bez nagrody był pięciokrotnie nominowany Kuroi Senji (ur. 1932) oraz Takami Jun (1907-1965). Do ciekawostek może należeć też to, że w obecnym składzie jury znalazł się pisarz Miyamoto Teru, który niegdyś bardzo surowo ocenił utwór Hebi o fumu 蛇を踏む? (przetłumaczony na język polski jako Nadepnętam na węż $a^{34}$ ), doprowadzając do lez jego autorkę, Kawakami Hiromi ${ }^{35}$ - laureatkę nagrody z 1996 roku, która obecnie zasiada z Miyamoto przy jednym stole jurorów (siedemdziesięcioletni Miyamoto jako najstarszy z kapituły naturalnie zasiada w samym środku stołu). A jeśli chodzi o kwestię obecności seniorów wśród laureatów Nagrody Akutagawy, nie wolno zapomnieć o najstarszej zwyciężczyni, mianowicie Kurodzie Natsuko - laureatce sto czterdziestej ósmej edycji z 2012 roku. Ta siedemdziesięciopięcioletnia autorka, łamiąc konwencję tradycyjnego zapisu tekstu japońskiego pionowo od strony prawej do lewej, napisała bardzo piękny utwór ab Sango abさんご(Ab sango)o fabule zasadzonej na wspomnieniach z dzieciństwa głównej bohaterki, fundując czytelnikom gratkę - lekturę czytaną w poziomie od lewej do prawej ${ }^{36}$.

\section{Zakończenie - przyszłość nagrody}

Częsty i powszechny jest pogląd, że dobra literatura to taka, która odzwierciedla ducha konkretnych czasów niczym starannie wypolerowane lustro. Nagroda Akutagawy, której historia rozpoczyna się w roku 1935, pełni rolę takiego lustra już ponad 80 lat. Pisane przez jurorów i wyczekiwane przez czytelników z niecierpliwością senpyō - recenzje nominowanych utworów - są natomiast odzwierciedleniem i diagnozą mniej lub bardziej dynamicznych zmian, jakie zachodzą we współczesnej literaturze japońskiej.

Dzięki temu, że Nagrodę Akutagawy przyznaje się w styczniu i lipcu, jest ona tematem dominującym w spragnionych sensacji mediach i intryguje nawet tych, którzy z literaturą mają niewiele wspólnego. Być może przyczynia się wówczas do wzrostu liczby czytelników książek dopiero debiutujących pisarzy.

Dlatego też zawarte na wstępie słowa Kikuchiego można by po latach nieco zmodyfikować. Istotnie, literatura nieczytana może jest jak samolot, który nie potrafi wzbić się w przestworza, ale w tym wypadku paliwem napędowym są właśnie media. To właśnie one stały się kolejnym nieodzownym, czwartym już elementem systemu Nagrody Akutagawy oprócz obrad jury, werdyktu i wreszcie recenzji jurorów. Otwarta na media i współpracują-

34 H. Kawakami, Nadepnęłam na węża, tłum. B. Słomka, Kraków 2010.

35 Y. Ogawa et al., op. cit., s. 290.

36 N. Kuroda, ab sango, Tōkyō 2013. 
ca z nimi nagroda rozwija się więc zgodnie z duchem czasów. A przecież właśnie to miał na myśli Kikuchi, ustanawiając ją w 1935 roku, a więc 82 lata temu.

Dopełnieniem jakże aktualnych słów Kikuchiego w kwestii nieczytania literatury może być wypowiedź obecnie najstarszego i najsurowszego jurora nagrody, także jej laureata w 1977 roku za powieść Hotaru gawa 蛍川 (Rzeka świetlików), Miyamoto Teru:

Jako długoletni juror nagrody mogę stwierdzić, że w zastraszającym tempie maleje ilość utworów, które mogłyby wprawić w zachwyt nawet najmniej wymagającego jurora. To chyba znak czasu - od wejścia w XXI wiek ludzie czytają mniej, nie wymagając od literatury zbyt dużo. $\mathrm{W}$ takich warunkach na pewno trudno jest młodym autorom uprawiać literaturę. Ale to właśnie autorom i utworom zdolnym przezwyciężyć te niesprzyjające pisarstwu czasy dedykowana jest Nagroda Akutagawy ${ }^{37}$.

\section{Bibliografia}

Kawaguchi Norihiro, Akutagawa Shō monogatari, Tōkyō: Basilico, 2013.

—, Akutagawa Shō no subete no yōna mono, portal informacyjny na temat wszystkich edycji nagrody, jej uczestników, nominowanych utworów, z recenzjami jurorów w formie tabelek, http:// prizesworld.com/akutagawa/ [dostęp: 01.07.2017].

Kōno Kensuke, Tōki to shite no bungaku: katsuji - kenshō - media, Tōkyō: Shin’yōsha, 2003.

Kōno Taeko, Shiryō o yuka ni nagetsuketa koto mo aru, „Bungeishunjū” 2014, nr 3.

Kuroda Natsuko, ab sango, Tōkyō: Bungeishunjū, 2013.

Melanowicz Mikołaj, Formy $w$ literaturze japońskiej, Kraków: Wydawnictwo Uniwersytetu Jagiellońskiego, 2003.

Miyamoto Teru, Miyamoto Teru vs. Murakami Ryū. Hokano shō to ha sekinin mo kinchōkan mo chigaimasu. Senkōiin tokubetsu taidan, „Bungeishunjū” 2014, nr 3.

Nagai Tatsuo, Kaisō Akutagawa. Naoki Shō, Tōkyō: Bungeishunjū, 1982.

Nihon gendai bungaku daijiten. Jinmei. Jikō hen, red. Miyoshi Yukio, Takemori Ten’yū, Yoshida Hiro’o, Asai Kiyoshi, Tōkyō: Meijishoin, 1994.

Nihon gendai shōsetsu daijiten, red. Asai Kiyoshi, Satō Masaru, Tōkyō: Meijishoin, 2009.

Ogawa Yōko, Kawakami Hiromi, Kawakami Mieko, Wataya Risa, Akutagawa Shō 150 kai kinen tokushū. Sakka no honne daizadankai, „Bungeishunjū” 2014, nr 3.

Saeki Kazumi, Akutagawa Shōo toranakatta meisakutachi, Tōkyō: Asahi Shinbun, 2009.

Toyoda Kenji, Sorezore no Akutagawa Shō Naoki Shō, Tōkyō: Bungeishunjū, 2004.

Ukai Tetsuo, Akutagawa Shō no nazo o toku. Zen senpyō kanzen dokuha, Tōkyō: Bungeishunjū, 2015.

37 Miyamoto Teru, Miyamoto Teru vs. Murakami Ryū. Hokano shō to ha sekinin mo kinchōkan mo chigaimasu. Senkōiin tokubetsu taidan, „Bungeishunjū" 2014, nr 3, s. 262. 